\title{
Feeding ecology of dominant larval myctophids in an upwelling area of the Humboldt Current
}

\author{
Laura Rodríguez-Graña ${ }^{1,3, *}$, Leonardo Castro ${ }^{3}$, Marcelo Loureiro ${ }^{2}$, \\ Humberto E. González ${ }^{4,5}$, Danilo Calliari ${ }^{1}$ \\ ${ }^{1}$ Sección Oceanología, and ${ }^{2}$ Sección Vertebrados, Facultad de Ciencias, Universidad de la República, Iguá 4225, CP 11400, \\ Montevideo, Uruguay \\ ${ }^{3}$ Laboratorio de Oceanografía Pesquera y Ecología Larval, Departamento de Oceanografía, and ${ }^{4}$ Centro de Investigaciones \\ Oceanográficas del Pacífico Sur-Oriental (COPAS), Universidad de Concepción, PO Box 160-C, Concepción, Chile \\ ${ }^{5}$ Instituto de Biología Marina, Universidad Austral de Chile, PO Box 567, Valdivia, Chile
}

\begin{abstract}
The feeding of 2 sympatric larval myctophids, Diogenichthys laternatus and Triphoturus mexicanus aff. oculeus, was analyzed in an upwelling area off northern Chile $\left(23^{\circ} \mathrm{S}, 71^{\circ} \mathrm{W}\right)$. Diel feeding period, feeding incidence, feeding selectivity and diet overlap was estimated under different environmental conditions: coastal and oceanic areas and 2 depth strata in summer and winter 1997. Analyses were based on larval stomach contents and microplankton abundance estimates. Larval tooth morphology and relationships between larval length, mouth width and prey size were explored. Both species fed on the most abundant microplankton layer during daylight, and both preferred copepods and nauplii, although the diet of D. laternatus was more diverse. As expected, the diets of these species tended to overlap in periods and areas where food was more abundant, but diets differed under conditions of low food availability. The 50 to $100 \mathrm{~mm}$ size range dominated the size spectrum of ingested prey in both species. The smallest prey width was constant for the entire range of larval sizes. The largest prey width was variable both within and between species, and increased with larval size. Regression analyses of mouth size and body length showed a potential relationship in D. laternatus and a linear relationship in T. mexicanus aff. oculeus. Prey ingested by D. laternatus were wider than those ingested by $T$. mexicanus aff. oculeus at equal larval sizes. The species presented differences in dentition patterns (hook-like teeth and pharyngeal structures in $D$. laternatus, conical teeth in T. mexicanus aff. oculeus). Opportunistic feeding and the feeding characteristics of both species should favor persistence and high abundances in the upwelling area of the Humboldt Current.
\end{abstract}

KEY WORDS: Diogenichthys laternatus · Triphoturus mexicanus · Triphoturus oculeus · Larval feeding $\cdot$ Myctophid $\cdot$ Upwelling $\cdot$ Humboldt Current

Resale or republication not permitted without written consent of the publisher

\section{INTRODUCTION}

The Humboldt Current is a highly productive, large marine ecosystem, where some of the largest finfish fisheries of the world are located. Its productivity is due to coastal upwelling that occurs all year round, especially along the coast of northern Chile and Peru (Blanco et al. 2001). The high spatial and temporal hydrographic variability of this area results in pulses of production (Daneri et al. 2000) that affect the distribution and feeding of the very abundant fish species, particularly during their early stages of development. Myctophids have received little attention, despite their high abundance in this area and their importance as food for pelagic and demersal fishes (Acuña 1986). Furthermore, due to their diel vertical migrations (Gjösaeter 1981, Roe \& Badcock 1982, Willis \& Pearcy 1982) and selective predation on zooplankton (Go- 
relova 1983, Pakhomov et al. 1996, Moku et al. 2000, Watanabe et al. 2002), myctophids are likely to significantly affect vertical carbon fluxes (Pakhomov et al. 1996).

Myctophid feeding has been mainly studied in adult and juvenile life stages (Tyler \& Pearcy 1975, Gorelova 1977, Hopkins \& Baird 1985, Young \& Blaber 1986, Rissik \& Suthers 2000, Watanabe et al. 2002). The feeding habits of myctophids are closely linked to their vertical migratory behavior: (1) migration to the surface for feeding at night (epipelagic migrators; Gorelova 1975, 1983, Hopkins \& Baird 1985, Watanabe et al. 2002), and (2) migration and feeding within the mesopelagic depth range (mesopelagic migrators; Clarke 1978, Kinzer \& Schultz 1985, Hopkins \& Gartner 1992). These differing behaviors are particularly evident in oligotrophic areas of tropical and subtropical oceanic regions (Clarke 1978, Hopkins \& Baird 1985, Kinzer \& Schultz 1985), where myctophid species that feed in surface strata at night tend to segregate vertically. In productive areas and/or high latitudes, the diel feeding cycles are less evident (Tyler \& Pearcy 1975, Pearcy et al. 1979, Young \& Blaber 1986, Moku et al. 2000). Species-specific migration patterns may reflect adaptations that reduce inter-specific competition when food resources are scarce (Kinzer \& Schultz 1985, Hopkins \& Gartner 1992). In productive areas (e.g. upwelling systems), a higher degree of overlap in distribution and feeding depth may be expected (Tyler \& Pearcy 1975), although temporal segregation has also been suggested (Young \& Blaber 1986).

Few studies have analyzed the feeding of myctophid larvae (Röpke 1996, Balbontín et al. 1997, Llanos 1998, Sabatés \& Saiz 2000, Sassa \& Kawaguchi 2004), and even fewer have addressed the relationship between their feeding and vertical migration (Sameoto 1982, Röpke 1996). Larvae feed mainly during daylight hours when they actively select certain prey sizes, and ontogenetic changes in prey selection may occur (Sabatés \& Saiz 2000, Sassa \& Kawaguchi 2004). Trophic overlap between Diogenichthys atlanticus and Hygophum bruuni larvae is important in areas and periods with high productivity off coastal areas of the South Pacific (32³3' S; Balbontín et al. 1997, Llanos 1998), but is significantly lower in North Pacific open waters, suggesting resource partitioning (Sassa \& Kawaguchi 2004).

In this study, we focused on Diogenichthys laternatus (Garman, 1899) and Triphoturus mexicanus aff. oculeus (Gilbert, 1890) (this species was previously identified as T. mexicanus southern population, see 'Results'). Both species are among the most abundant myctophids off northern Chile, where adults and larvae occur during most of the yearly cycle (Loeb \& Rojas 1988, Rodríguez-Graña \& Castro 2003), irrespective of El Niño/La Niña periods (Loeb \& Rojas 1988).
In contrast to other upwelling regions (Olivar et al. 1992, Moser \& Smith 1993, Olivar \& Shelton 1993), mesopelagic larvae in northern Chile are associated with upwelling plumes and occur closer to coastal areas (Rodríguez-Graña \& Castro 2003). Due to the very narrow continental shelf $(<20 \mathrm{~km})$, upwelling plumes develop near-shore at depths $>1000$ m (off the Península de Mejillones, Escribano et al. 2002). These plumes may entrain both oceanic and coastal waters, affecting the distribution and retention of mesopelagic and pelagic larvae (Rojas et al. 2002). At other regions, complex oceanographic structures define the distribution of myctophid species (Sassa et al. 2004). Off the Península de Mejillones, Diogenichthys laternatus and Triphoturus mexicanus aff. oculeus may co-occur in the same depth range in the coastal area (Rojas et al. 2002, Rodríguez-Graña \& Castro 2003), but are more vertically segregated in the oceanic area (Rodríguez-Graña \& Castro 2003, L. Rodríguez-Graña unpubl. data).

The high abundance, persistence (even during El Niño periods), and differences in morphology and distribution, make Diogenichthys laternatus and Triphoturus mexicanus aff. oculeus particularly well suited for the investigation of potential feeding adaptations to the highly variable conditions prevailing in the Humboldt Current. In this study, we examined the feeding of these sympatric myctophids in the upwelling area off northern Chile, based on analyses of larval stomach contents and microplankton samples collected simultaneously at the same locations during 2 seasons. We estimated the diel feeding period, feeding incidence, feeding selectivity and diet overlap under different environmental conditions (coastal and oceanic areas, surface [0 to $50 \mathrm{~m}$ ] and deeper strata [50 to $150 \mathrm{~m}$ ], summer and winter 1997). Because of the differences in morphology and distribution range of the juvenile and adult stages of the 2 species, we also expected differences in feeding habits between their larvae. Alternatively, the high productivity in the ecosystem may allow the 2 species to occur sympatrically despite similarities in feeding habits.

\section{MATERIALS AND METHODS}

Field work. Ichthyoplankton samples were collected off the Península de Mejillones, northern Chile $\left(23^{\circ} \mathrm{S}\right.$, $71^{\circ} \mathrm{W}$ ) during 2 oceanographic cruises in the austral summer (January 11 to 16) and winter (July 1 to 5) 1997 (Fig. 1). Larvae were collected from oblique hauls at 2 strata ( 0 to $50 \mathrm{~m}$ and 50 to $150 \mathrm{~m}$ ) at 8 stations in summer and 12 stations in winter, using a Tucker trawl net ( $1 \mathrm{~m}^{2}$ mouth, $300 \mu \mathrm{m}$ mesh) equipped with a flowmeter. Stations were located from ca. 6 to 200 nautical miles (n miles) offshore. Plankton samples were preserved in $4 \%$ buffered formaldehyde at sea. 


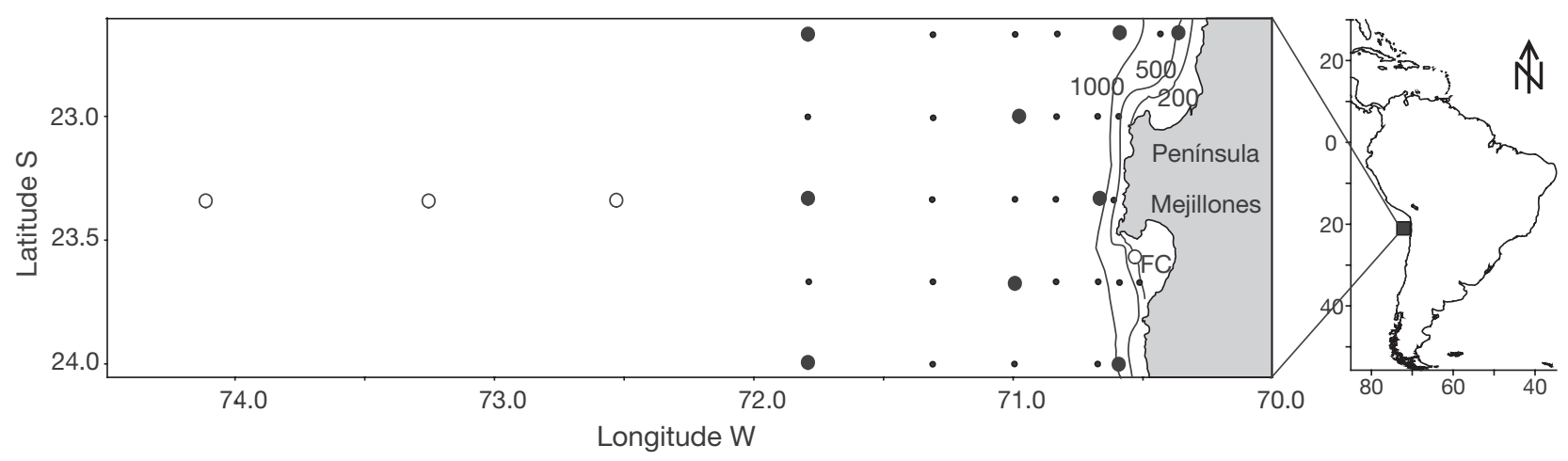

Fig. 1. Sampling grid covered during cruises in January and July 1997. •: oceanographic stations; •: ichthyoplankton stations sampled in January and June 1997; O: ichthyoplankton stations sampled only in June 1997. FC = coastal front station

Estimation of food availability in the environment was based on the analysis of microplankton samples collected with 301 Niskin bottles from 40 and $100 \mathrm{~m}$ depth at the same stations and times as larval sampling. Samples were filtered through a $25 \mu \mathrm{m}$ sieve and preserved in $4 \%$ buffered formaldehyde at sea. Larvae fed during daylight hours (see 'Results'), so only microplankton samples corresponding to daylight hours were considered $(n=38)$.

Laboratory analyses. Specimens of Diogenichthys laternatus and Triphoturus mexicanus aff. oculeus were sorted for gut content analysis. Prior to dissection, body length and mouth width of the larvae were measured. Body length was measured as notochord length in preflexion and flexion larvae, and standard length in postflexion larvae. Mouth width was determined in the ventral view, as the width between the posterior edges of the maxillae (Sabatés \& Saiz 2000).

The stomach contents of Diogenichthys laternatus and Triphoturus mexicanus aff. oculeus were examined under stereoscopic microscope. Larvae were mounted on microscope slides and covered with a glycerin drop to avoid dispersion of the gut contents during dissection. Prey items were identified, measured and counted under an inverted microscope. Prey size (defined as its maximum width), was estimated according to Busch (1996).

Microplankton was identified and counted under inverted microscope. Only those organisms that have been reported to be prey or potential prey for fish larvae (copepods, copepodids, nauplii, invertebrate eggs, ostracods, tintinnids, and mollusk and polychaete larvae) were included in the analyses.

Tooth morphology and number in the dentary and maxilla were determined for Diogenichthys laternatus $(\mathrm{n}=8)$ and Triphoturus mexicanus aff. oculeus $(\mathrm{n}=3)$. Distance between teeth was measured and the presence or absence of specialized teeth (e.g. pharyngeal teeth) was recorded. Osteological observations were made with cleared and stained specimens according to Potthoff (1984).
Data analysis. Feeding rhythms were analyzed by considering the diet of larvae collected at all stations during January and July at 00:30, 01:30, 02:30, 03:30, 04:30, 05:30, 06:30, 08:30, 10:30, 11:30, 12:30, 13:30, $14: 30,15: 30,16: 30,17: 30$ and 23:30 h. Differences in the presence/absence of stomach contents between day and night hours were tested using the MannWhitney $U$-test (Zar 1996). Contents were classified into 3 categories: (1) not digested or only slightly digested (entire and recognizable items), (2) half digested (not complete but still recognizable items), (3) digested (disintegrated, unrecognizable items).

Incidence of feeding (IF; proportion of larvae with prey in the stomach) was examined for each species, period, area and stratum. This percentage was considered a measure of feeding success.

Feeding ratio $\left(\mathrm{FR}_{i}\right.$ mean number of prey items per stomach) was determined for each species and for different larval size classes.

Composition of the diet was summarized as percent number $(\mathrm{N} \%)$ and frequency of occurrence ( $\mathrm{F} \%)$ of prey items. The product of these 2 factors gives an index of relative dietary importance (Govoni et al. 1983), referred to as N \% × F \% (Sánchez-Velasco et al. 1999). Empty stomachs were excluded from this particular analysis.

Diversity of prey items was estimated using the Shannon-Wiener Index (Shannon \& Weaver 1963, Margalef 1989):

$$
H^{\prime}=-\sum d_{i} \log _{2} d_{i r} \quad d_{i}=N_{i} / N
$$

where $d_{i}$ is the proportion of item $i$ in the diet, $N_{i}$ is the number of individuals in the sample with the item $i, N$ is the total number of individuals in the sample and $\Sigma d_{i}=1$. This index ranges from 0 when only 1 species is present, to $H_{\text {max }}^{\prime}$, which is the value when all species are equally abundant. It was applied to guts with contents made up by recognizable prey for each area and stratum, both in January and July 1997. 
The diets of the 2 species were compared using an index of dietary overlap, the similarity index $D$ (Schoener 1968):

$$
D=1-0.5 \times \sum\left|\left(p_{i}-q_{i}\right)\right|
$$

where $p_{i}$ is the proportion of item $i$ in the diet of species $p$ and $q_{i}$ is the proportion of item $i$ in the diet of species $q$. $D$ ranges between 0 (diets do not overlap) and 1 (diets completely overlap). This index was applied for both areas and depth strata in January and July 1997.

Prey preference is usually estimated by a selectivity index based on the relative proportions of items in stomachs and their availability to the larvae in the water. However, estimating prey availability is a major source of uncertainty in the application of this type of index to field data. The average concentration of prey does not necessarily reflect the frequency with which they are encountered by larvae, while there are also difficulties associated with sampling in the same parcel of water on spatial scales that approximate the ambit of a larval fish. Prey preference was estimated using the Chesson alpha index $(\alpha)$ (Chesson 1978):

$$
\alpha_{j}=\left(d_{j} / k_{j}\right) /\left(\sum d_{i} / k_{i}\right), \quad i=1, \ldots \mathrm{n}
$$

where $\mathrm{n}$ is the number of prey items per sample, $d_{j}$ has the same meaning as in Eq. (1), $k_{j}$ is the proportion of prey $j$ available to the larvae in the water, and $d_{i}$ and $k_{i}$ are the same proportions for the ith prey. The expected value for random feeding is a function of the number of food items, $1 / \mathrm{n}$. The index varies between 0 and 1 with values above $1 / \mathrm{n}$ indicating preference and those below $1 / \mathrm{n}$ indicating avoidance. The Chesson $\alpha$ index is unaffected by the relative abundance of food types, thus allowing meaningful comparisons between samples (Lechowicz 1982). Only prey items found in the microplankton samples were included in this analysis.

Correlations between larval length and mouth width were estimated for each species. Analysis of covariance (ANCOVA; Zar 1996) was used to test potential differences between species in the relationships between (1) mouth width (dependent variable) and body length (co-variable), (2) prey width (dependent variable) and body length (co-variable), and (3) prey width (dependent variable) and mouth width (co-variable).

\section{RESULTS}

\section{Oceanographic conditions}

During January 1997, a weak upwelling event occurred and an upwelling filament extended from the coast and northwest towards open waters. Surface temperatures were lower inside the filament $\left(<14^{\circ} \mathrm{C}\right)$ than outside $\left(15\right.$ to $\left.19^{\circ} \mathrm{C}\right)$. Sea surface temperature was lower in the coastal area $\left(14^{\circ} \mathrm{C}\right)$ than in the oceanic area $\left(19^{\circ} \mathrm{C}\right)$. During July 1997 (austral winter), the study area was under the influence of an El Niño event (Sobarzo \& Figueroa 2001) and surface temperatures were warmer than in summer. Temperature ranged between 16 and $19^{\circ} \mathrm{C}$ over most of the region, with the exception of a few stations in, and close to, the coastal zone $\left(<14^{\circ} \mathrm{C}\right)$. Detailed descriptions of the oceanographic conditions during the study can be found elsewhere (González et al. 2000, Sobarzo \& Figueroa 2001, Rodríguez-Graña \& Castro 2003).

\section{Taxonomic considerations}

Larvae of the genus Triphoturus were collected, in which T. mexicanus is the single species recognized for the eastern Pacific Ocean (Moser \& Ahlstrom 1996). However, the pigmentation pattern of larvae collected in this study clearly differed from $T$. mexicanus but was similar to that of former $T$. oculeus larvae (Ahlstrom 1972, Brewer 1973, Wisner 1976). A recent study based on mtDNA cytochrome b gene sequences and pigmentation patterns in larvae found differences between $T$. mexicanus from northern Pacific and southern Pacific areas, suggesting that these forms are probably separate species (Rodríguez-Graña et al. 2004). Therefore, in this study we refer to T. mexicanus as T. mexicanus affinis oculeus.

\section{Spatial distribution and larval size range}

Diogenichthys laternatus and Triphoturus mexicanus aff. oculeus were present in oceanic and coastal areas. Spatial overlap was higher in January than in July, main-ly in the coastal area and the shallow strata. $D$. laternatus evidenced a wide vertical distribution range, including both the shallow and deep strata. $T$. mexicanus aff. oculeus presented a shallower vertical distribution, similar in coastal and oceanic areas, with higher abundances occurring in the shallow stratum (Fig. 2). Small larvae, mostly at pre-flexion and flexion stages, dominated during the whole period. D. laternatus size ranged between 2.60 and $10.50 \mathrm{~mm}$ (mean \pm SD: $4.87 \pm 1.09 \mathrm{~mm})$. T. mexicanus aff. oculeus size ranged between 2.45 and $11.87 \mathrm{~mm}$ (mean \pm SD: $4.79 \pm$ $1.33 \mathrm{~mm})$.

\section{Daily feeding pattern and feeding incidence}

In total, guts from 1830 specimens of Diogenichthys laternatus and 614 specimens of Triphoturus mexicanus aff. oculeus were examined. All guts taken from 


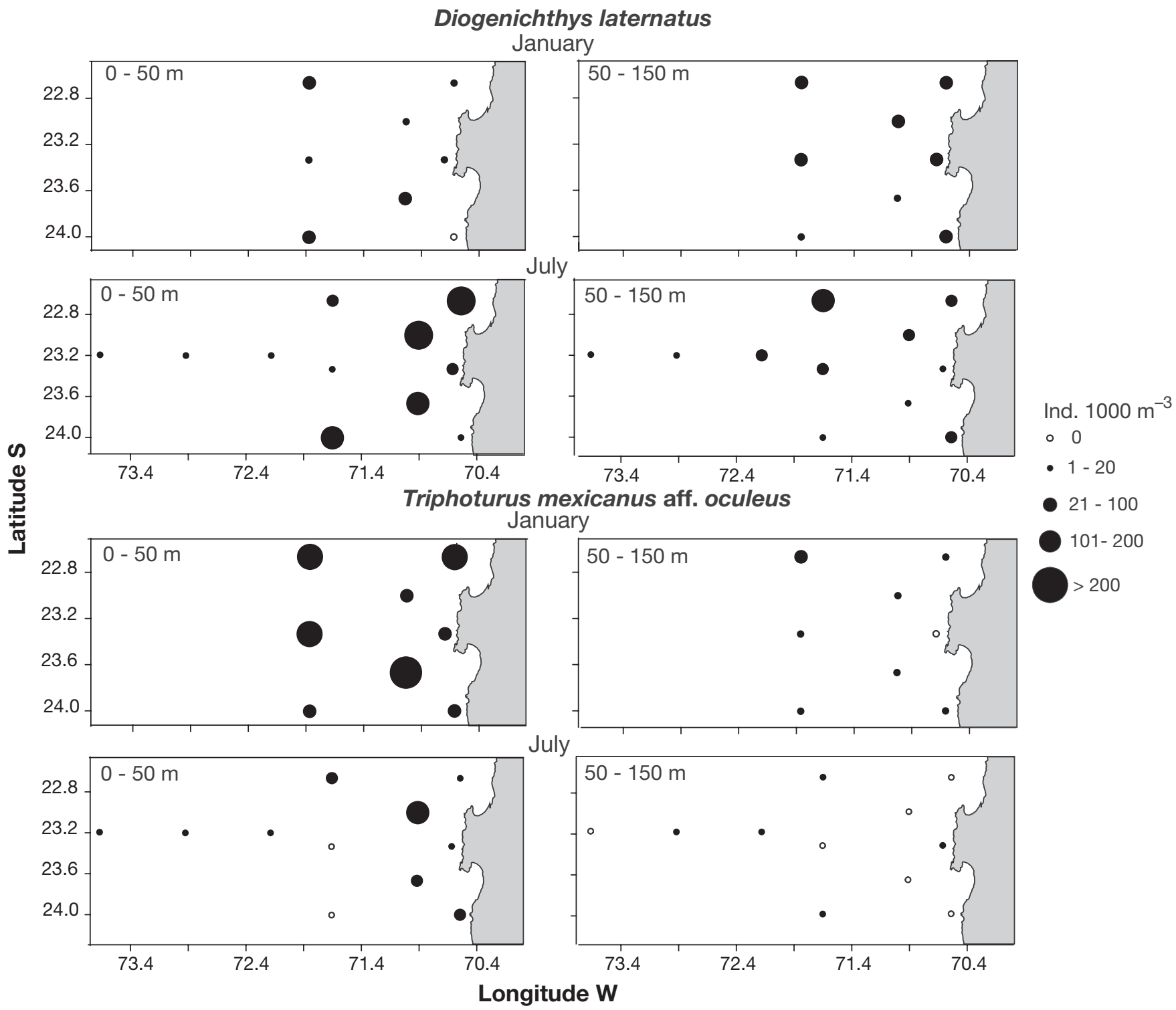

Fig. 2. Diogenichthys laternatus and Triphoturus mexicanus aff. oculeus. Horizontal distribution of larvae discriminated by species, periods and strata. During January, the sampling design considered stations up to ca. $90 \mathrm{n}$ miles offshore

larvae of both species during dark hours were empty (514 D. laternatus, 206 T. mexicanus aff. oculeus). D. laternatus larvae contained food at all daylight hours sampled, except at 17:30h, when this species was absent from the samples. Food was also present in daylight samples of $T$. mexicanus aff. oculeus, except in specimens caught at 08:30 and 13:30 h (Fig. 3). Consequently, IF was higher during daylight hours than during dark hours (Mann Whitney U-test, p $<0.01$, $\mathrm{n}=1830$ for D. laternatus and $\mathrm{n}=614$ for T. mexicanus aff. oculeus). Thus, analyses of feeding incidence, diet composition, prey diversity and relative importance of food items only considered samples collected during daylight hours ( $\mathrm{n}=1316$ for $D$. laternatus and $\mathrm{n}=408$ for T. mexicanus aff. oculeus).
The smallest larvae with gut contents were $2.6 \mathrm{~mm}$ for Diogenichthys laternatus and $3.4 \mathrm{~mm}$ for Triphoturus mexicanus aff. oculeus. IF for D. laternatus was $26.7 \%$ considering the whole set, and $17.6 \%$ for $T$. mexicanus aff. oculeus. In January, D. laternatus presented the highest IF in the deeper stratum of the oceanic area $(31.2 \%)$, while in July, the highest IF occurred in the shallower stratum of the coastal area $(35.3 \%)$. T. mexicanus aff. oculeus presented the highest IF in the deeper stratum of the coastal area in January $(25.0 \%)$ and in the deeper stratum of the coastal and oceanic areas in July (33.3\%).

The proportion of prey that was undigested was $67.8 \%$ for Diogenichthys laternatus and $63.0 \%$ for Triphoturus mexicanus aff. oculeus during the day- 
Diogenichthys laternatus

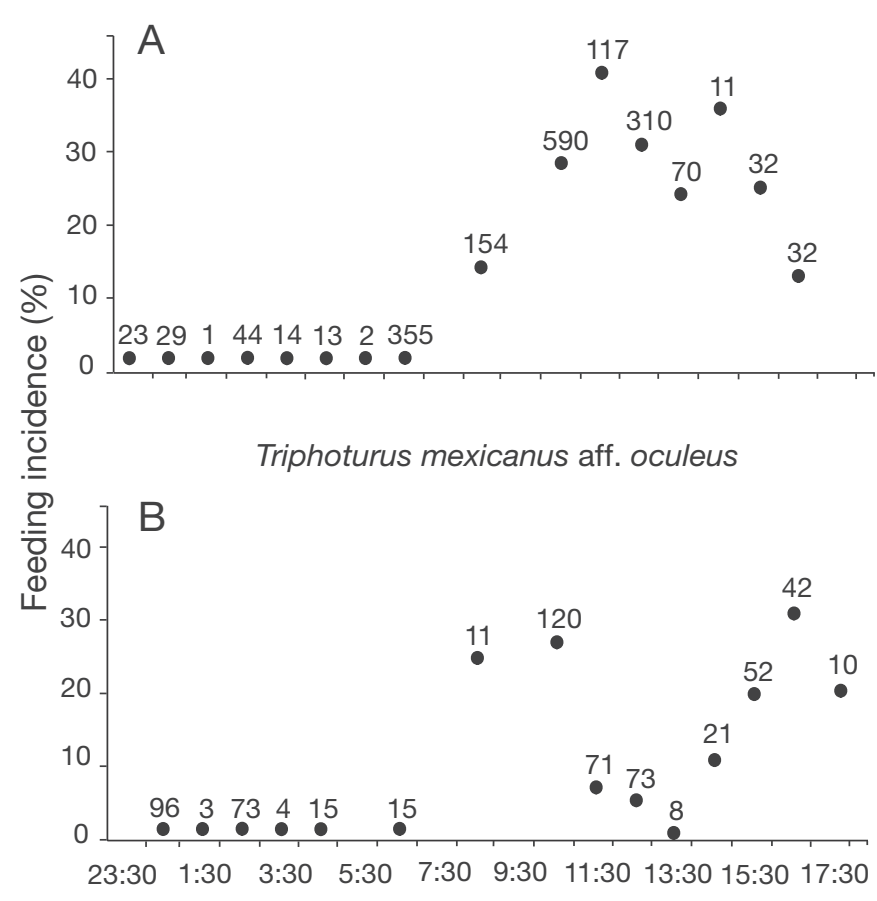

Diogenichthys laternatus

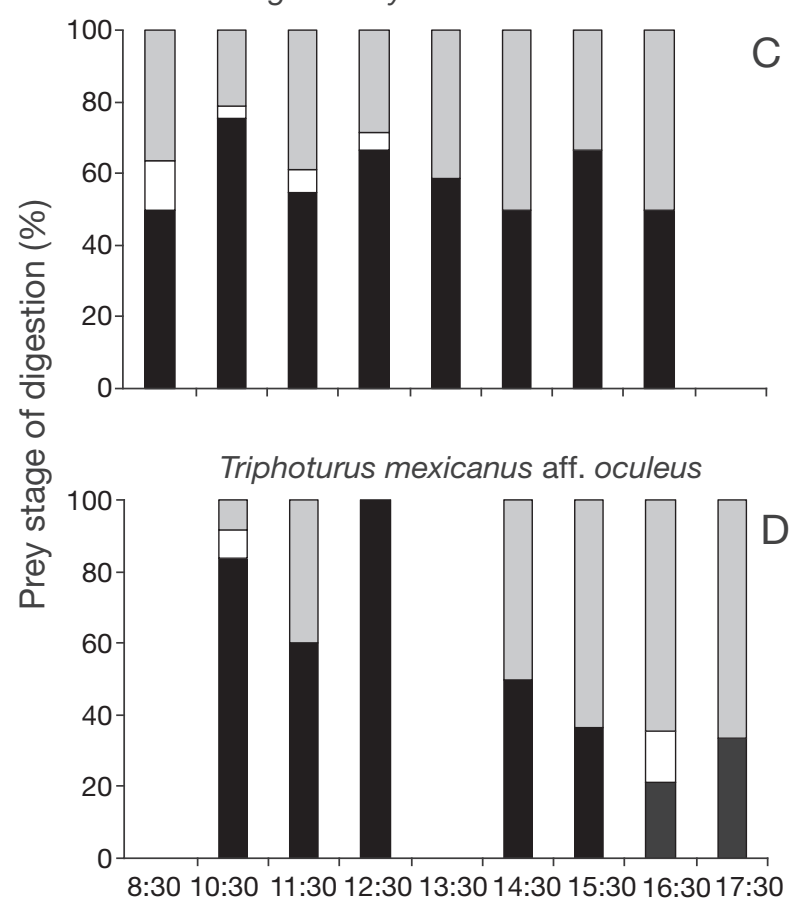

Time of the day (h)

Fig. 3. Diogenichthys laternatus and Triphoturus mexicanus aff. oculeus. (A,B) Feeding incidence as a function of time of day in January and July 1997, off the Península de Mejillones; values above data points indicate number of larvae examined. Horizontal bar denotes dark and daylight hours. (C,D) Degree of digestion of prey in larval guts expressed as a percentage: undigested (black bars), half-digested (white bars), highly digested (gray bars). D. laternatus larvae were not collected at 17:30 h; T. mexicanus aff. oculeus larvae collected at 08:30 and 13:30 h had no gut contents

light hours considered. D. laternatus presented a more extended feeding period than $T$. mexicanus aff. ocu-leus. For this species, undigested contents dominated between mid morning (10:30 h) and midday (Fig. 3).

The mean FR was 1.3 (SD: 0.8; range 0 to 8 prey per stomach) for Diogenichthys laternatus and 1.5 (SD: 1.3; range 0 to 8 prey per stomach) for Triphoturus mexicanus aff. oculeus. For both species the number of prey per stomach was relatively constant with increasing body length (Fig. 4).

\section{Diet composition, prey diversity and dietary overlap}

The diet of Diogenichthys laternatus was composed of invertebrate eggs, nauplii, ostracods, copepods, copepodids, larval mollusks and polychaetes, juvenile Nemertea, tintinnids and a non-identified spore-like item. A low number of $D$. laternatus larvae $(n=6)$ fed on dinoflagellates from the genus Protoperidinium. Triphoturus mexicanus aff. oculeus had a diet composed by nauplii, ostracods, copepods, copepodids, invertebrate eggs and fish larvae.

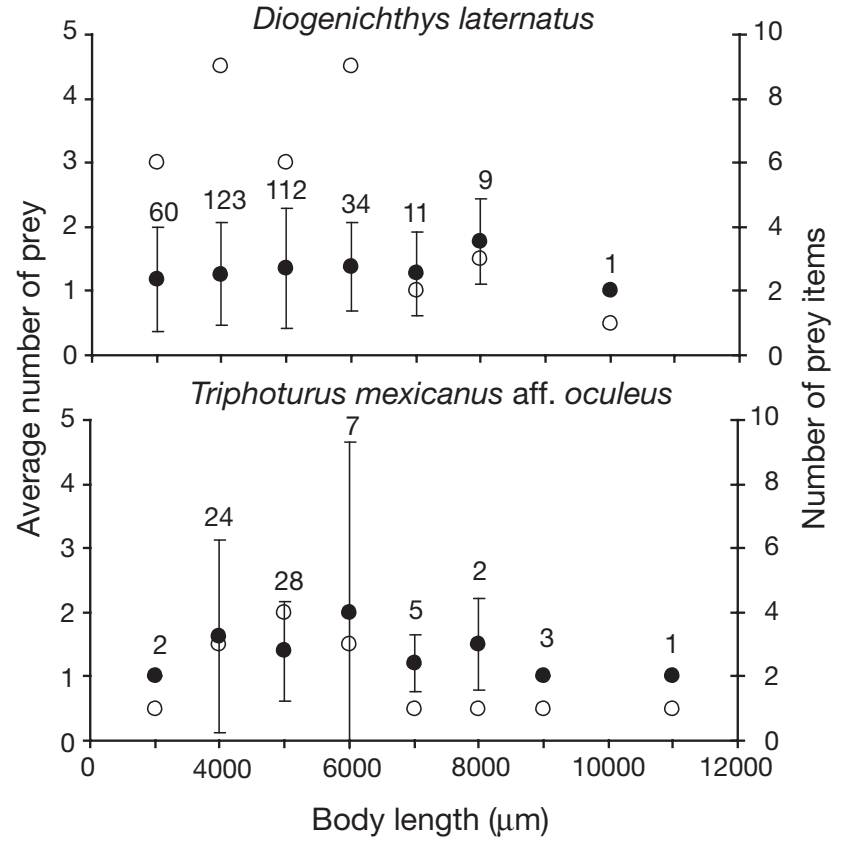

Fig. 4. Diogenichthys laternatus and Triphoturus mexicanus aff. oculeus. Mean number of prey $(\bullet)$ and mean number of prey categories found in the gut of individual larvae as function of larval size class (O). Bars are standard deviations 


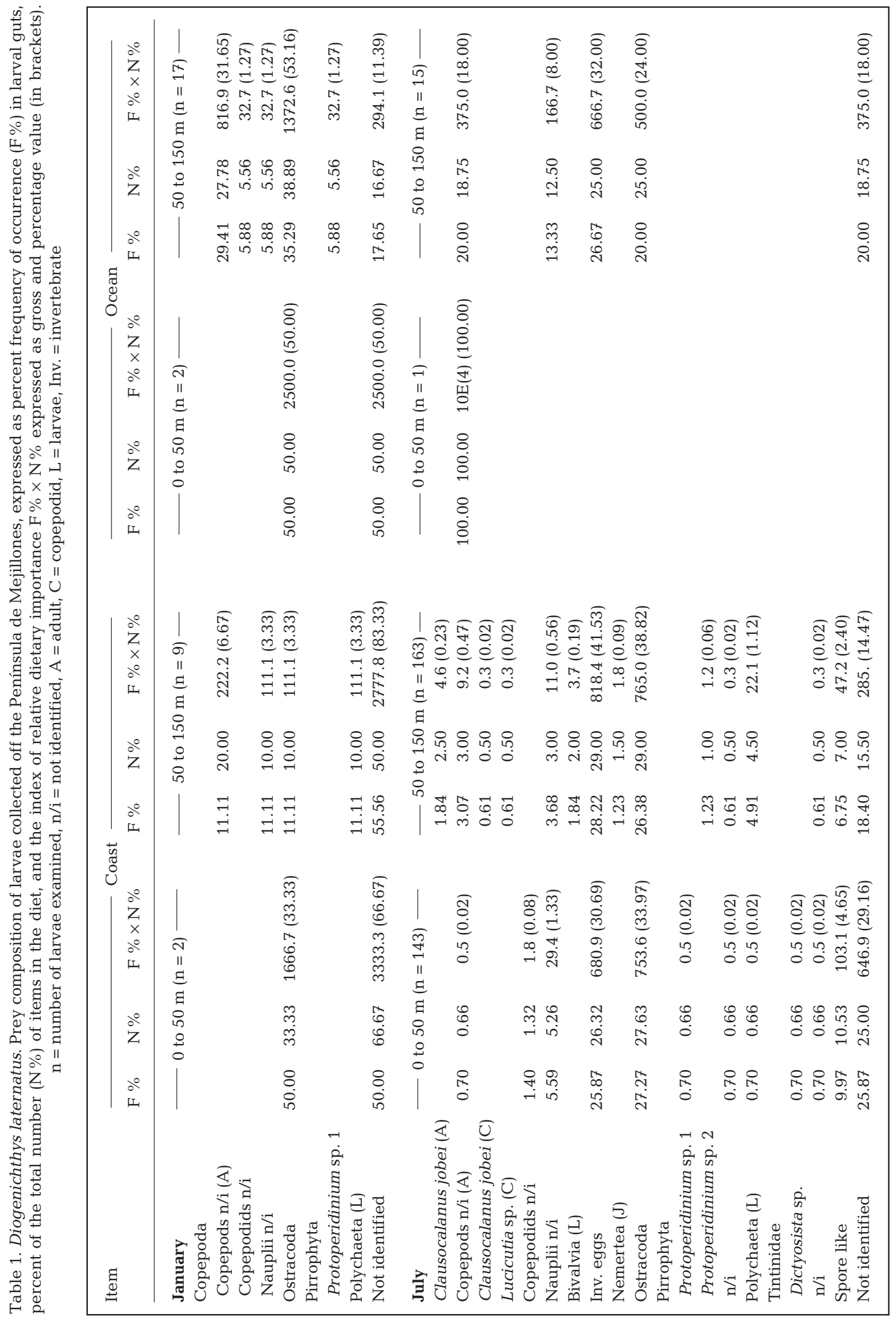


The relative importance index showed differences between periods, areas and species. Diogenichthys laternatus larvae fed on a wide variety of prey, dominated by ostracods, calanoid copepods, nauplii and invertebrate eggs (Table 1). Triphoturus mexicanus aff. oculeus larvae fed mainly on nauplii, copepodids and ostracods (Table 2).

Prey diversity ( $H^{\prime}$ index) for Diogenichthys laternatus was highest in the deeper stratum of the coastal area in January $\left(H^{\prime}=1.9\right)$ (Table 3$)$. $H^{\prime}$ could only be estimated for Triphoturus mexicanus aff. oculeus in the shallower stratum of the coastal area, and was higher here than for D. laternatus $\left(H^{\prime}=1\right)$. During July, $H^{\prime}$ was high in the coastal area for both species. D. laternatus showed slightly higher prey diversity in the deep stratum $\left(H^{\prime}=2.2\right)$ than in the shallow stratum, while T. mexicanus aff. oculeus presented equal diversity for both strata $\left(H^{\prime}=1.4\right)$ (Table 3$)$. There was a tendency for the number of prey types to decrease with increasing larval size; this behavior was more evident for $D$. laternatus than $T$. mexicanus aff. oculeus (Fig. 4).

Dietary overlap ( $D$ index) between Diogenichthys laternatus and Triphoturus mexicanus aff. oculeus was negligible during January in the shallow stratum of the coastal area $(D=0$; Table 3$)$. D. laternatus ate ostracods and T. mexicanus aff. oculeus ate copepods and nauplii. During the same period, but in the oceanic area, $D$ was 0.5 in the deep stratum: both species fed on copepods. In July, $D$ was highest in the shallow stratum of the coastal area $(D=0.6)$, where both species fed on copepods, copepodids, nauplii, invertebrate eggs and ostracods. In some cases, the $D$ index could not be calculated due to the dominance of unidentified items.

\section{Food availability and predation selectivity}

Microplankton abundance and relative composition varied between coastal and oceanic areas in January. In the coastal area, copepodids and nauplii were more numerous; in the oceanic area, copepods, invertebrate eggs and polychaete larvae were more abundant (Table 4). Most microzooplankters were more abundant in samples collected at $40 \mathrm{~m}$, with the exception of nauplii, which were equally abundant at 40 and $100 \mathrm{~m}$ in the coastal area. In July, all microplankton taxa were more abundant in the coastal area at $40 \mathrm{~m}$ (Table 4).

The Chesson alpha index evidenced variable preferences according to period and strata (Table 3). Diogenichthys laternatus preferred copepods, larval polychaetes and invertebrate eggs. Triphoturus mexicanus aff. oculeus preferred copepods, copepodids, invertebrate eggs and nauplii. In some cases, selectivity could

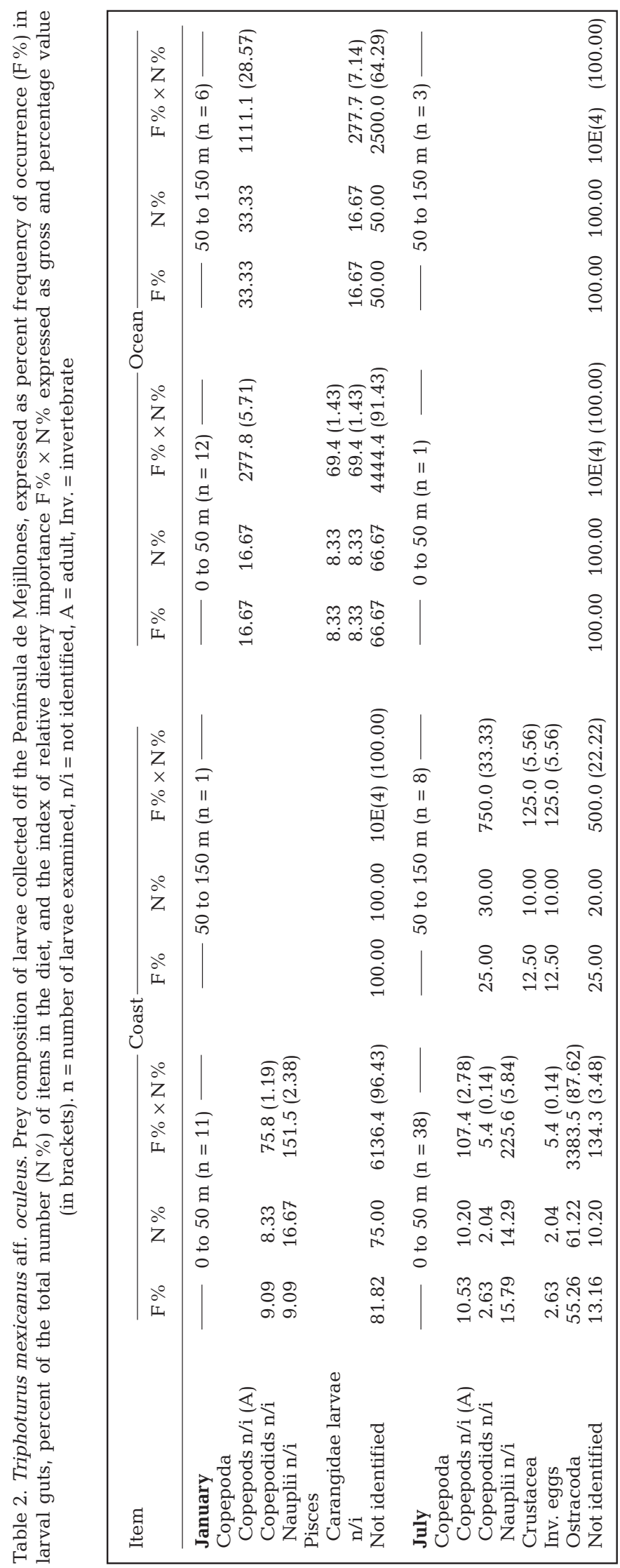


Table 3. Diogenichthys laternatus and Triphoturus mexicanus aff. oculeus. Shannon-Wiener Index $\left(H^{\prime}\right)$, Similarity index $(D)$ and Chesson alpha index in coastal and oceanic areas off the Península de Mejillones during January and July 1997 for the 2 depth strata investigated. The Chesson alpha index is given for prey categories with $\alpha>1 / \mathrm{n}$. -: no occurrence. Copep. = copepods, Copepd. $=$ copepodids, Inv. eggs $=$ invertebrate eggs, Polych. $=$ polychaetes

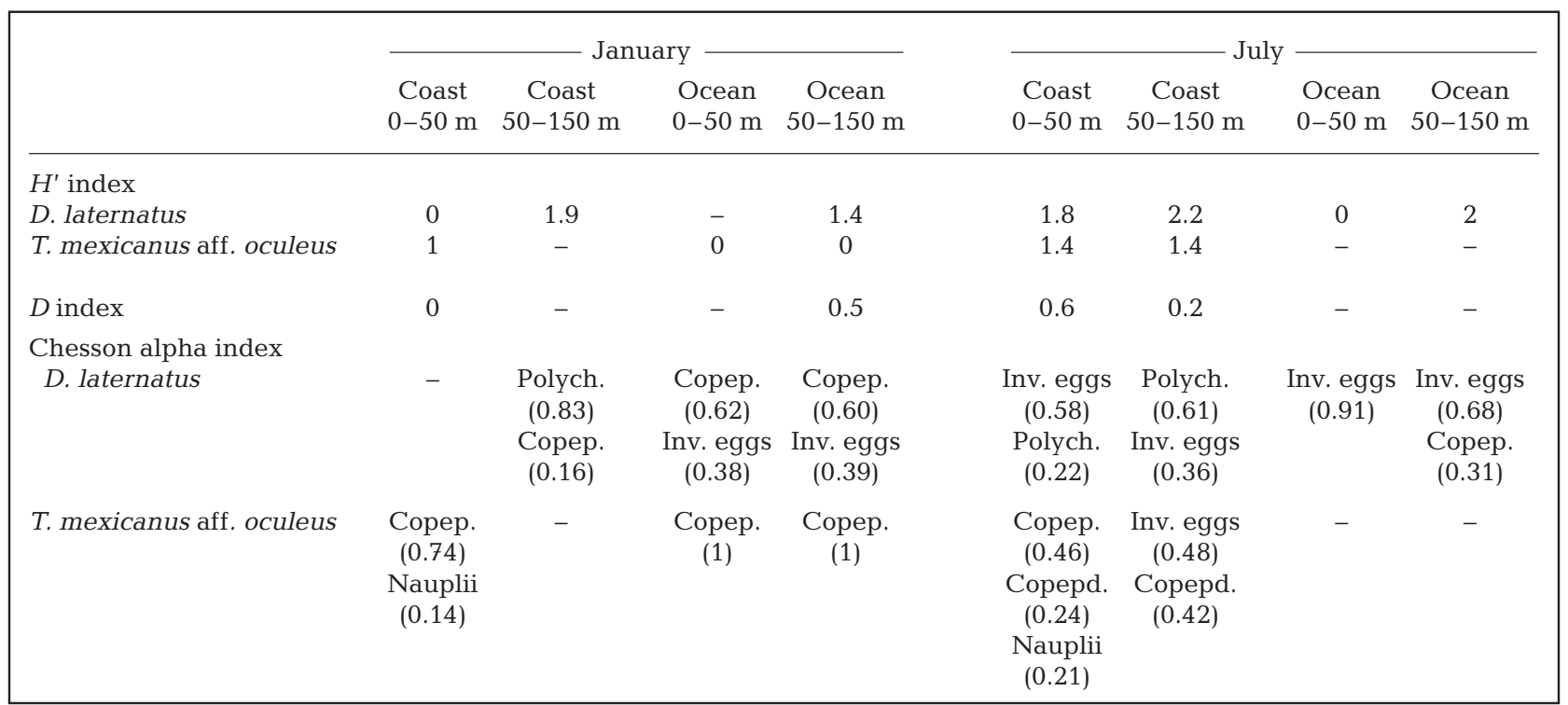

Table 4. Density of main microzooplankton taxa (individuals (ind.) $\mathrm{m}^{-3}$ ) collected during January and July 1997 at coastal and oceanic sites off the Península de Mejillones, for the 2 depth strata investigated

\begin{tabular}{|c|c|c|c|c|c|c|c|c|c|c|}
\hline \multirow{2}{*}{$\begin{array}{l}\text { Depth strata } \\
\text { (m) }\end{array}$} & \multicolumn{2}{|c|}{ Copepods } & \multicolumn{2}{|c|}{ Copepodids } & \multicolumn{2}{|c|}{ Nauplii } & \multicolumn{2}{|c|}{ Inv. eggs } & \multicolumn{2}{|c|}{ Polychaetes } \\
\hline & Coast & Ocean & Coast & Ocean & Coast & Ocean & Coast & Ocean & Coast & Ocean \\
\hline \multicolumn{11}{|l|}{ January } \\
\hline $0-50$ & 4 & 10 & 20 & 1 & 69 & 9 & 31 & 46 & 0.3 & 4 \\
\hline $50-150$ & 2 & 5 & 4 & 1 & 65 & 34 & 4 & 19 & 1 & 0 \\
\hline \multicolumn{11}{|l|}{ July } \\
\hline $0-50$ & 6 & 5 & 2 & 0.5 & 19 & 10 & 6 & 1 & 0.4 & 0.1 \\
\hline $50-150$ & 2 & 1 & 2 & 1 & 11 & 5 & 1 & 1 & 0.1 & 0 \\
\hline
\end{tabular}

not be estimated because some organisms were present in the diet but were absent from most microplankton samples (e.g. ostracods, spore-like item and bivalve larvae); these organisms were not considered for calculations of the Chesson alpha index.

\section{Morphometric relationships and prey size}

The relationship between mouth size and body length followed a potential pattern for Diogenichthys laternatus $\left(\mathrm{r}^{2}=0.65, \mathrm{n}=738, \mathrm{p}<0.01\right)$ and a linear pattern for Triphoturus mexicanus aff. oculeus $\left(\mathrm{r}^{2}=0.65, \mathrm{n}=357, \mathrm{p}<0.01\right)$ (Fig. 5). ANCOVA analyses evidenced (1) significant differences in mouth width between species $(\mathrm{p}<0.05, \mathrm{n}=165)$ and an effect of body length on mouth width $(p<0.01$, $\mathrm{n}=165)$, (2) significant differences in prey width between species $(\mathrm{p}<0.01, \mathrm{n}=262)$ and an effect of body length on prey width ( $p<0.01, n=262)$, and (3) a significant effect of mouth width on prey width ( $\mathrm{p}<0.01, \mathrm{n}=165$ ) (Fig. 5).

The 50 to $100 \mu \mathrm{m}$ range dominated the size spectrum of ingested prey for both species (Fig. 6); Diogenichthys laternatus prey ranged from 47 to $893 \mu \mathrm{m}$, and that of Triphoturus mexicanus aff. oculeus from 33 to $455 \mu \mathrm{m}$. The width of the smallest prey was fairly constant throughout the range of larval sizes. The width of the largest prey increased with body length and mouth width, although data were rather noisy (Fig. 5). Prey width increased linearly with body length $\left(\mathrm{r}^{2}=0.10, \mathrm{p}<0.01, \mathrm{n}=212\right)$ and with mouth size $\left(\mathrm{r}^{2}=0.10, \mathrm{p}<0.01, \mathrm{n}=116\right)$ for D. laternatus. For T. mexicanus aff. oculeus, prey 

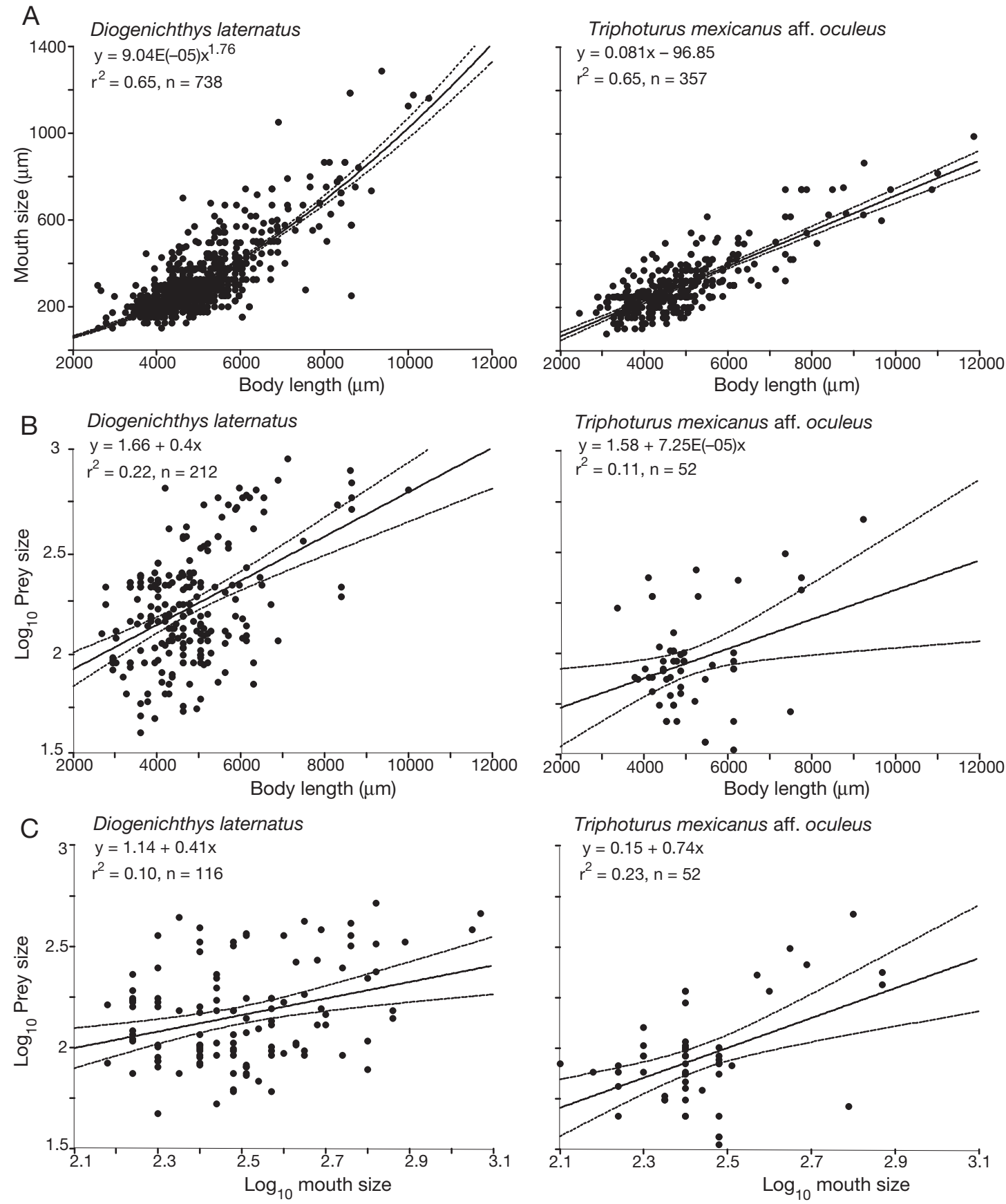

Fig. 5. Diogenichthys laternatus and Triphoturus mexicanus aff. oculeus. (A) Larval length and mouth size. (B) Log 10 prey width and larval body length. (C) $\log _{10}$ prey width and $\log _{10}$ mouth width

width increased linearly with body length $\left(\mathrm{r}^{2}=0.23\right.$, $\mathrm{p}<0.01, \mathrm{n}=52$ ), but increased following a potential pattern with mouth width $\left(\mathrm{r}^{2}=0.22, \mathrm{p}<0.01, \mathrm{n}=52\right)$.

\section{Dentition morphology}

Diogenichthys laternatus first presented teeth at body lengths of $4.6 \mathrm{~mm}$ (pre-flexion stage). The num- ber of teeth in the dentary and in the premaxilla increased with developmental stage of the larvae. Inter-teeth distance was irregular (30 to $70 \mu \mathrm{m})$. Teeth were conical, except for the last 3 teeth in the dentary which were hook-like and pointing forward (Fig. 7A,B). This species also presented 2 pharyngeal teeth in the dorsal position with 4 cuspids each (Fig. 7C,D). These specialized teeth were present only in post-flexion stages. Triphoturus mexicanus aff. 


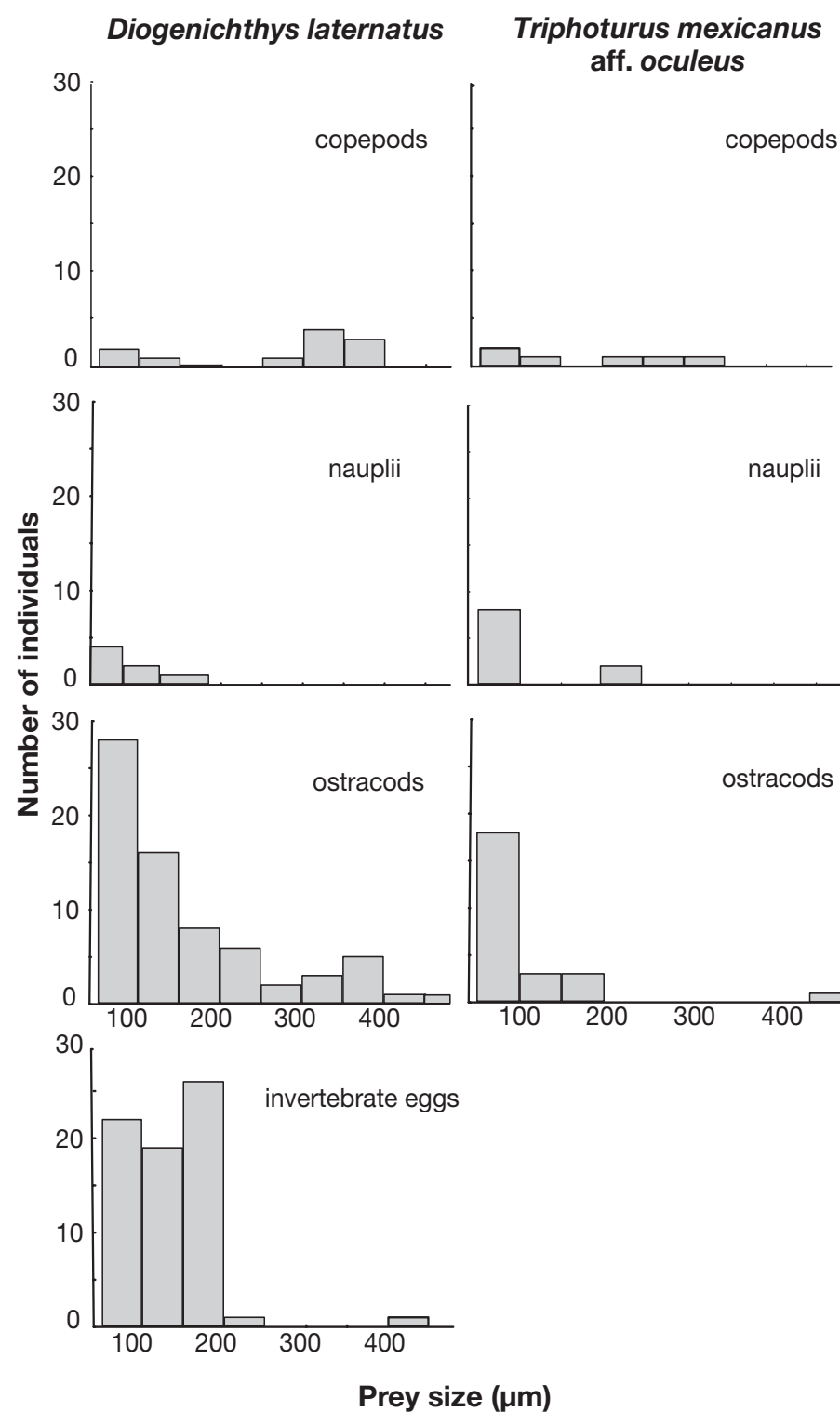

Fig. 6. Diogenichthys laternatus and Triphoturus mexicanus aff. oculeus. Size (width) frequency distribution of most frequent food items determined from gut content analyses oculeus first presented teeth at body lengths of $3.7 \mathrm{~mm}$ (pre-flexion stage; minimum larval size range analyzed). This species presented larger and sharper teeth than D. laternatus. Teeth were homogeneously distributed in the dentary (ca. $30 \mu \mathrm{m}$ ) and in the premaxilla, and were conical (Fig. 7E,F). No pharyngeal teeth were found. Table 5 summarizes the main dentition characteristics for both species.

\section{DISCUSSION}

The main issues to be highlighted are novel results referring to myctophid larval feeding in a major upwelling area: extended diurnal feeding patterns, significantly smaller minimum sizes for feeding larvae than previously reported, variable diet overlap depending on prey abundance, and the presence of distinctive dentition patterns in very early larval stages.

\section{Diel feeding rhythms and feeding incidence}

Diogenichthys laternatus and Triphoturus mexicanus aff. oculeus larvae are visual predators, feeding only during daylight. This behavior is relatively common among fish larvae, including myctophids (Sabatés \& Saiz 2000, Sassa \& Kawaguchi 2004), and differs from that reported for myctophid juveniles and adults in tropical and subtropical regions which feed mainly at night (Clarke 1978, Hopkins \& Baird 1985, Kinzer \& Schultz 1985, Watanabe et al. 2002). Ontogenic changes in feeding rhythms correlate with changes in the morphology and physiology of the visual system during development (Evans \& Browman 2004). In this study, both species showed an extended feeding cycle during daylight hours (ca. 08:30 to 17:30 h), corroborated by the presence of undigested prey in all daylight samples.

The minimum size of larvae with gut content found here was smaller for both species than that reported earlier for myctophids in other regions (2.6 mm for Diogenichthys laternatus and $3.4 \mathrm{~mm}$ for Triphoturus mexicanus aff. oculeus versus $4.1 \mathrm{~mm}$ for Diaphus garmani and Myctophum asperum; Sassa \& Kawaguchi 2004). No information about length at hatching or at yolk absorption is available for these species in the Humboldt Current. For the California Current region, the length at hatching is $2 \mathrm{~mm}$ for T. mexicanus and $2.9 \mathrm{~mm}$ for D. laternatus (Moser \& Ahlstrom 1996). If these values are valid for the Humboldt Current 

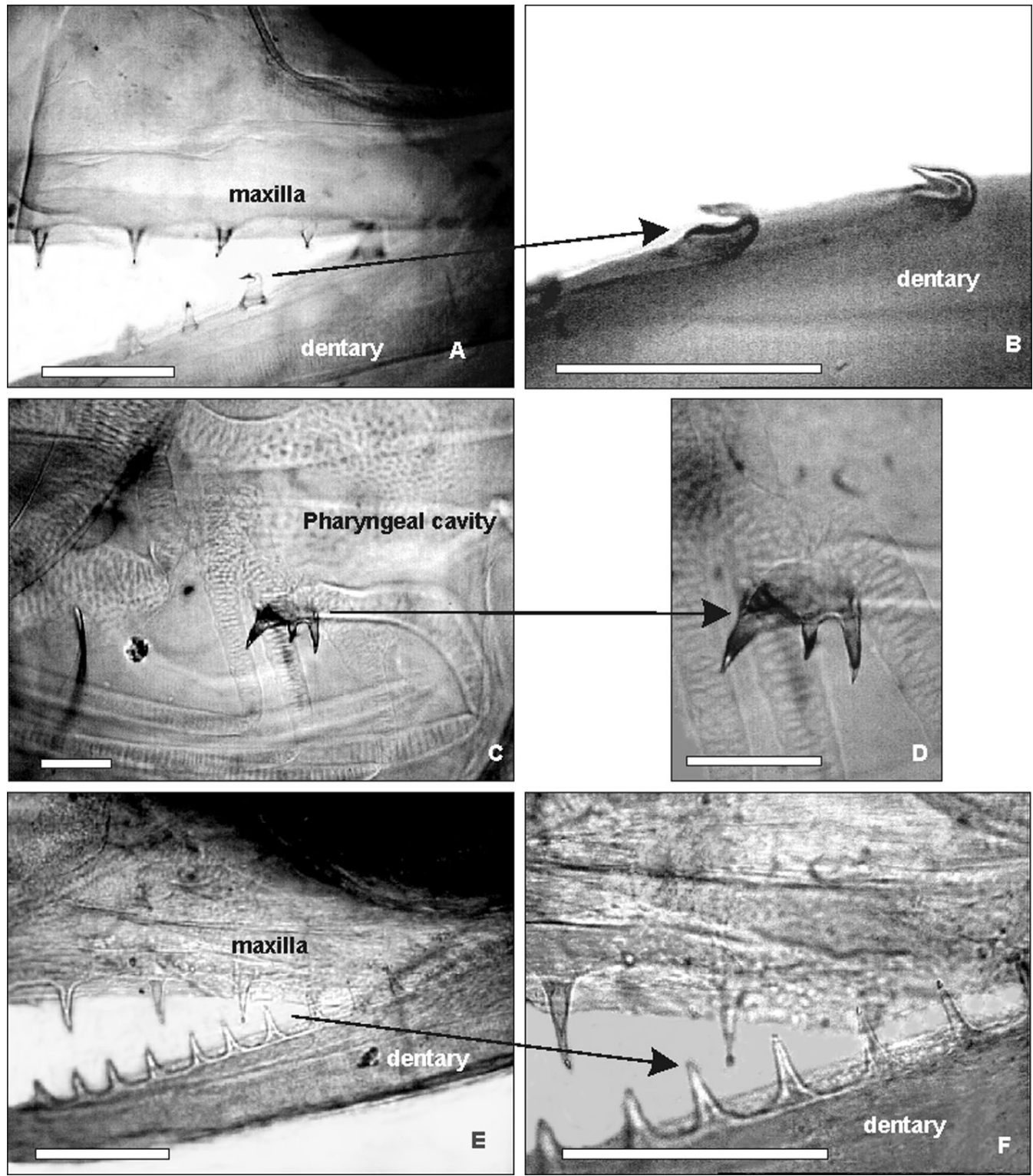

Fig. 7. Diogenichthys laternatus and Triphoturus mexicanus aff. oculeus. Dentition of both larval myctophids. (A) Teeth in the upper and lower jaw of D. laternatus. (B) Teeth in the back of the dentary of D. laternatus. (C,D) Pharyngeal teeth in D. laternatus. (E) Teeth in the upper and lower jaw of T. mexicanus aff. oculeus. (F) Teeth in the back of the dentary of T. mexicanus aff. oculeus. In all cases scale bar $=90 \mu \mathrm{m}$

system, our results imply that at least $D$. laternatus starts feeding at a very early age.

However, the feeding incidence of both Diogenichthys laternatus and Triphoturus mexicanus aff. oculeus was relatively low $(<30 \%)$ compared to values reported for other myctophid larvae in the Humboldt Current (Balbontín et al. 1997). Food availability does not seem to be the cause for such low feeding incidences, since microplankton abundance during this study was similar to other seasons in nearby areas (Bal- bontín et al. 1997, Llanos 1998, Castro et al. 2000). Our feeding incidence results could be underestimated due to (1) the predominance of small larvae that are usually less successful in capturing prey (Hunter 1980) and have higher defecation rates (Fange \& Grove 1979), and (2) enhanced defecation rates as a result of the higher than average temperatures (Hurst 2004) that occurred in the study area during July as consequence of an El Niño event (Blanco et al. 2002, Carr et al. 2002). 


\section{Prey composition and ontogenetic changes in diet}

Diogenichthys laternatus and Triphoturus mexicanus aff. oculeus were mainly zooplanktivores and ingested copepods, copepodids, nauplii, invertebrate eggs, ostracods and fish larvae. These food items are similar to those described for other myctophid larvae (Balbontín et al. 1997, Llanos 1998, Sabatés \& Saiz 2000, Sassa \& Kawaguchi 2004), with the exception of fish larvae ( $T$. mexicanus aff. oculeus), which had not been reported to be prey for larvae of this family before. D. laternatus was more euriphagous during early stages, a common trend among fish larvae (Hunter 1984) which could reflect a limited selection capability of the smallest individuals. Subsequent specialization will depend on the energetic requirements of the larvae, their morphology and their swimming capabilities. However, we should be cautious in the interpretation of this pattern because of the prevalence of small larvae during this study.

Ostracods are important in the diet of some adult myctophids at mid and low latitudes (Merrett \& Roe 1974, Sameoto 1988, Hopkins \& Gartner 1992), and have recently been reported to be important items for larvae in the NW Pacific (Sassa \& Kawaguchi 2004). The high incidence of ostracods in the diets of Diogenichthys laternatus and Triphoturus mexicanus aff. oculeus could have been favored by their high abundance in the pelagic realm (Angel 1999) and their wide distribution in the water column (between

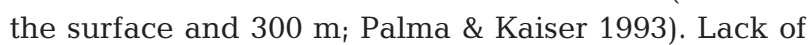
data on distribution and abundance of ostracods in the area, and the fact that this group was absent from most of the microplankton samples (probably due to the coarse vertical sampling), prevented selectivity estimations. It seems unlikely that ingestion of ostracods occurred in the nets during sampling, because the size of ostracods ingested was in most cases $(85 \%)$ smaller than the pore-size of the ichthyoplankton nets $(300 \mu \mathrm{m})$. Microscale spatial distributions of prey organisms and larvae are required to better understand resource partitioning and food selection in this area.

The 50 to $100 \mu \mathrm{m}$ size range dominated the prey size-spectrum of both species. That is the rule for most larval fish (Hunter 1984), in which the mean size of prey increases with increasing predator size (measured as body length or mouth width; Hunter 1984, Juanes 1994). In this study, relationships between prey size and larval body length or larval mouth width were positive but highly variable (Fig. 5). The range of prey sizes typically increases during larval development: as maximum prey size increases, minimum prey size changes only slightly (asymmetric pattern in predator size-prey size distribution; Scharf et al. 2000). The lower limit is determined by the energetic requirements of the larvae (Hunter 1984) and the upper limit could be determined by the mouth width (Shirota 1970). However, during development, the average prey size increases more slowly than the physical capabilities of the larvae allow (Gerking 1994, Pepin \& Penney 1997). Hence, besides mouth size, other factors such us physiological aspects and behavior also contribute to the prey selection process.

\section{Feeding location and dietary overlap}

A higher number of Diogenichthys laternatus larvae with gut contents were found in areas of high microplankton densities: open ocean during January and near the coast during July. Triphoturus mexicanus aff. oculeus larvae showed higher feeding incidence in the coastal area during both periods. Maximum diet overlap occurred in areas with high food availability, which is the expected pattern (Schoener 1974). During January, the maximum diet overlap occurred in the oceanic area and in the deep stratum, which coincided with highest microplankton abundance. The presence of higher microplankton abundances in oceanic areas compared to coastal areas is an unexpected pattern. Shortly before sampling, a cold upwelling filament characterized by a high phytoplankton concentration was observed extending from the coast to ca. $90 \mathrm{n}$ miles offshore (Sobarzo \& Figueroa 2001, RodríguezGraña \& Castro 2003). These hydrographic structures may transport organisms from the coastal area to open waters, and supply food for the larvae in adjacent oceanic areas. During July, maximum diet overlap occurred in the shallow stratum of the coastal area, which coincided with the highest microplankton density recorded during that period.

\section{Dentition and its possible adaptive significance}

Differences in teeth morphology between Diogenichthys laternatus and Triphoturus mexicanus aff. oculeus could reflect the type of prey ingested during the first stages of development. Strongly hooked teeth are found in adults of both $D$. laternatus and T. mexicanus (Paxton 1972); our results show that these structures develop earlier in the former species. In early D. laternatus larvae, specialized dentition would favor feeding when food is scarce. Hook-like teeth may prevent the escape of prey through the posterior area of the jaws, while irregular teeth distribution is related to feeding on prey of diverse shapes and sizes (Govoni 1987, Mullaney \& Gale 1996). This interpretation is consistent with our findings of a higher diversity of 
prey types and the occurrence of a wider prey size spectrum in D. laternatus. Accordingly, this species showed an extended vertical distribution off the Península de Mejillones, mainly in open waters (L. Rodríguez-Graña unpubl. data). The role of pharyngeal teeth (involved in the crushing of prey with hard structures like valves) during early stages of development remains unclear, considering that fish larvae swallow their prey whole (Hunter 1984). T. mexicanus aff. oculeus had homogeneous dentition, including the shape and distance between teeth. These characteristics could be associated with inhabiting an environment with higher prey availability, consistent with its shallower distribution in the upper $50 \mathrm{~m}$ (RodríguezGraña \& Castro 2003).

\section{Final considerations}

Diogenichthys laternatus and Triphoturus mexicanus aff. oculeus larvae that coexist in an upwelling area off northern Chile showed flexible feeding behavior, shifting their diet depending on food availability, and showed an opportunistic feeding response as described for adults of other myctophids in temperate waters (Williams et al. 2001). These characteristics make both species less vulnerable to changes in the abundance of any particular food item. Even though D. aternatus and T. mexicanus aff. oculeus had a number of prey taxa in common, their diets overlapped primarily in periods or areas where food was more abundant. Under conditions of lower food availability, both species seemed to have distinct diets. In coastal areas, these species co-occur with the large population of Engraulis ringens (Loeb \& Rojas 1988, Rojas et al. 2002, Rodríguez-Graña \& Castro 2003), the diet of which overlaps with the lower size range found in this study for D. laternatus and T. mexicanus aff. oculeus (Llanos et al. 1996). A large mouth size in myctophids may help diminish interspecific competition with engraulids by extending the size range of potential prey. The suite of feeding traits of $D$. laternatus and $T$. mexicanus aff. oculeus must be important factors that favor their persistence and abundance in highly variable environments such as the upwelling area off northern Chile, even during El Niño years.

Acknowledgements. G. Asencio, P. Mejías, J. Madrid, C. Torres, C. Maturana, V. Ortíz, C. Krautz, R. Veas and M. Landaeta helped with larval sorting and taxonomical identification. A. Pacheco and L. Vidal helped with microplankton analyses. M. Gómez helped with identification of prey items. We thank F. Balbontín, B. Bergström, J. Modin, H. Wennhage, J. Paxton and anonymous reviewers who commented on and improved the manuscript. Analysis of stomach contents was performed at the Sección Oceanología, Universidad de la
República (Uruguay) and at the Laboratorio de Oceanografía Pesquera y Ecología Larval, Universidad de Concepción (Chile). Photographs were obtained at UNCIEP, Universidad de la República. This research was funded by grant FONDECYT 5960002-1996. LR-G was supported by the German Academic Exchange Service (DAAD) and the Graduate School, Universidad de Concepción.

\section{LITERATURE CITED}

Acuña E (1986) El recurso mictófidos (Pisces, Myctophidae): antecedentes en aguas chilenas y marco de referencia para su investigación. In: Arana P (ed) La pesca en Chile. Escuela de Ciencias del Mar, Universidad Católica de Valparaíso, p 315-339

Ahlstrom EH (1972) Distributional atlas of fish larvae in the California Current region: six common mesopelagic fishes-Vinciguerria lucetia, Triphoturus mexicanus, Stenobrachius leucopsarus, Leuroglossus stilbius, Bathylagus wesethi and Bathylagus ochotensis, 1955 through 1960. Calif Coop Ocean Fish Investig Atlas 17:1-306

Angel MV (1999) Ostracoda. In: Boltovskoy D (ed) South Atlantic zooplankton. Backhuys Publishers, Leiden, p 815-868

Balbontín F, Llanos A, Valenzuela V (1997) Sobreposición trófica e incidencia alimentaria en larvas de peces de Chile central. Rev Chil Hist Nat 70:381-390

Blanco JL, Thomas AC, Carr ME, Strub PT (2001) Seasonal climatology of hydrographic conditions in the upwelling region off northern Chile. J Geophys Res 106: 11451-11467

Blanco JL, Carr ME, Thomas AC, Strub PT (2002) Hydrographic conditions off northern Chile during the 1996-1998 La Nina and El Nino events. J Geophys Res 107:3017-3040

Brewer GD (1973) Midwater fishes from the Gulf of California and the adjacent eastern tropical Pacific. Bull Nat Hist Mus Los Angeles 242:1-47

Busch D (1996) Transition from endogenous to exogenous nutrition: larval size parameters determining the start of external feeding and size of prey ingested by Ruegen spring herring Clupea harengus. Mar Ecol Prog Ser 130: $39-46$

Carr ME, Strub PT, Thomas AC, Blanco JL (2002) Evolution of 1996-1999 La Nina and El Nino conditions off the western coast of South America: a remote sensing perspective. J Geophys Res 107:3236

Castro LR, Salinas GR, Hernández E (2000) Environmental influences on winter spawning of the anchoveta Engraulis ringens off central Chile. Mar Ecol Prog Ser 197:247-258

Chesson J (1978) Measuring preference in selective predation. Ecology 59:211-215

Clarke TA (1978) Diel feeding patterns of 16 species of mesopelagic fishes from Hawaiian waters. Fish Bull 76: 495-513

Daneri G, Dellarossa V, Quiñones R, Jacob B, Montero P, Ulloa O (2000) Primary production and community respiration in the Humboldt Current System off Chile and associated oceanic areas. Mar Ecol Prog Ser 197:41-49

Escribano R, Marín VH, Hidalgo P, Olivares G (2002) Physical-biological interactions in the pelagic ecosystem of the nearshore zone of the northern Humboldt Current System. In: Castilla JC, Largier JL (eds) The oceanography and ecology of the nearshore and bays in Chile. Proc Int Symp Linkages and Dynamics of Coastal Systems: Open Coast and Embayments, Santiago, Chile 2000. 
Ediciones Universidad Católica de Chile, Santiago, p 145-175

Evans BI, Browman HI (2004) Variation in the development of the fish retina. Am Fish Soc Symp 40:145-166

Fange R, Grove D (1979) Digestion. In: Hoar WS, Randall DJ, Brett JR (eds) Fish physiology, Vol 8. Academic Press, New York, p 161-260

Gerking SD (1994) Larval feeding. In: Gerking SD (ed) Feeding ecology of fishes. Academic Press, London, p 139-169

Gjösaeter J (1981) Abundance and production of lantern-fish (Myctophidae) in the western and northern Arabian Sea. Fiskdir Skr Ser Havunders 17:215-251

González HE, Sobarzo M, Figueroa D, Nöthig EM (2000) Composition, biomass and potential grazing impact of the crustacean and pelagic tunicates in the northern Humboldt Current area off Chile: differences between El Niño and non-El Niño years. Mar Ecol Prog Ser 195:201-220

Gorelova TA (1975) The feeding of fishes of the family Myctophidae. J Ichthyol 15:208-219

Gorelova TA (1977) Some characteristics of the nutrition of the young of nictoepipelagic and mesopelagic lanternfishes (Pisces, Myctophidae). Oceanology 17:220-222

Gorelova TA (1983) A quantitative assessment of consumption of zooplancton by epipelagic lanternfishes (family Myctophidae) in the Equatorial Pacific Ocean. J Ichthyol 23:106-113

Govoni JJ (1987) The ontogeny of dentition in Leistomus xanthurus. Copeia 4:1041-1046

Govoni JJ, Hoss DE, Chester AJ (1983) Comparative feeding of three species of larval fishes in the northern Gulf of Mexico: Brevoortia patronus, Leiostomus xanthurus, and Micropogonias undulatus. Mar Ecol Prog Ser 13:189-199

Hopkins TL, Baird RC (1985) Aspects of the trophic ecology of the mesopelagic fish Lampanyctus alatus (Myctophidae) in the Eastern Gulf of Mexico. Biol Oceanogr 3:285-313

Hopkins TL, Gartner JV Jr (1992) Resource-partitioning and predation impact of low-latitude myctophid community. Mar Biol 114:185-197

Hunter JR (1980) The feeding behaviour and ecology of marine fish larvae. In: Bardach JE, Magnuson JJ, May RC, Reinhart JM (eds) ICLARM Conf Proc 5. International Center of Living Aquatic Resources Management, Manila, p 287-330

Hunter JR (1984) Feeding ecology and predation of marine fish larvae. In: Lasker R (ed) Marine fish larvae: morphology, ecology and relation to fisheries. Washington Sea Grant Program, Seattle, p 33-77

Hurst TP (2004) Temperature and state-dependence of feeding and gastric evacuation in juvenile Pacific halibut. J Fish Biol 65:157-169

Juanes F (1994) What determines prey size selectivity in piscivorous fishes? In: Stouder DJ, Fresh KL, Feller RJ (eds) Theory and application in fish feeding ecology. South Carolina University Press, Columbia, p 79-100

Kinzer JR, Schultz K (1985) Vertical distribution and feeding patterns of midwater fish in the central equatorial Atlantic. I. Myctophidae. Mar Biol 85:313-322

Lechowicz MJ (1982) The sampling characteristics of electivity indices. Oecologia 52:22-30

Llanos AJ (1998) Composición y sobreposición dietaria del ictioplancton de la zona nerítica de la bahía Valparaíso. MSc thesis, Universidad de Concepción

Llanos A, Herrera G, Bernal P (1996) Prey size analysis in the diet of larvae of four clupeiforms in a coastal area of central Chile. Sci Mar 60:435-442

Loeb VJ, Rojas O (1988) Interannual variation of ichthyoplankton composition and abundance relations off northern Chile, 1964-83. Fish Bull 86:1-24

Margalef R (1989) Ecología, 2nd edn. Omega, Barcelona

Merrett NR, Roe HSJ (1974) Patterns and selectivity in the feeding of certain mesopelagic fish. Mar Biol 28:115-126

Moku M, Kawaguchi K, Watanabe H, Ohno A (2000) Feeding habits of three dominant myctophid fishes, Diaphus theta, Stenobrachius leucopsaurus and S. nannochir, in the subartic and transitional waters of the western North Pacific. Mar Ecol Prog Ser 207:129-140

Moser HG, Ahlstrom EH (1996) Myctophidae: lanternfishes. In: Moser HG (ed) The early stages of fishes in the California Current region. Calif Coop Ocean Fish Investig Atlas 33:387-475

Moser HG, Smith PE (1993) Larval fish assemblages of the California Current region and their horizontal and vertical distributions across a front. Bull Mar Sci 53:645-691

Mullaney MD, Gale LD (1996) Ecomorphological relationships in ontogeny: anatomy and diet in Gag, Mycteroperca microlepis (Pisces: Serranidae). Copeia 1:167-180

Olivar MP, Shelton PA (1993) Larval fish assemblages of the Benguela Current. Bull Mar Sci 53:450-474

Olivar MP, Rubiés P, Salat J (1992) Horizontal and vertical distribution patterns of ichthyoplankton under intense upwelling regimes off Namibia. S Afr J Mar Sci 12:71-82

Pakhomov EA, Perissinotto R, Mcquaid CD (1996) Prey composition and daily rations of myctophid fishes in the Southern Ocean. Mar Ecol Prog Ser 134:1-14

Palma S, Kaiser K (1993) Plancton marino de aguas chilenas. Ediciones Universitarias de Valparaíso, Universidad Católica de Valparaíso

Paxton J (1972) Osteology and relationships of the lanternfishes (Family Myctophidae). Bull Nat Hist Mus Los Angeles 13:1-81

Pearcy WG, Lorz HV, Peterson W (1979) Comparison of the feeding habits of migratory and non migratory Stenobranchius leucopsarus (Myctophidae). Mar Biol 51:1-8

Pepin P, Penney RW (1997) Patterns of prey size and taxonomic composition in larval fish: are there general sizedependent models? J Fish Biol 51(A):84-100

Potthoff T (1984) Clearing and staining techniques. In: Moser HG, Richards WJ, Cohen DM, Fahay MP, Kendall AW Jr, Richardson SL (eds) Ontogeny and systematics of fishes. Am Soc Ichthyol Herpetol Spec Pub 1:35-37

Rissik D, Suthers IM (2000) Enhanced feeding by pelagic juvenile myctophid fishes within a region of islandinduced flow disturbance in the Coral Sea. Mar Ecol Prog Ser 203:263-273

Rodríguez-Graña L, Castro LR (2003) Ichthyoplankton distribution off the Península de Mejillones $\left(23^{\circ} \mathrm{S}\right)$, under variable hydrographic conditions in two seasons of the El Niño, 1997. Hydrobiologia 501:59-73

Rodríguez-Graña L, Herrera G, Herrera L, Castro LR (2004) Divergence of two forms of Triphoturus in the eastern Pacific based on mtDNA cytochrome $b$ gene sequences and larval morphology. J Fish Biol 64:1455-1461

Roe HS, Badcock J (1982) The diel migrations and distributions within a mesopelagic community in the north-east Atlantic. Vertical migrations and feeding of fish. Prog Oceanogr 13:389-424

Rojas PM, Escribano R, Marín VH (2002) Fish larvae distribution off Mejillones Península (northern Chile) during coastal upwelling event in spring 1999: interactions with the cold upwelling plume. Fish Oceanogr 11(4):233-244

Röpke A (1996) Do larvae of mesopelagic fishes in the Arabian Sea adjust their vertical distribution to physical and biological gradients? Mar Ecol Prog Ser 101:223-235

Sabatés A, Saiz E (2000) Intra- and interspecific variability in 
prey size and niche breadth of myctophiform fish larvae. Mar Ecol Prog Ser 201:261-271

Sameoto DD (1982) Vertical distribution and abundance of the Peruvian anchovy Engraulis ringens and sardine Sardinops sagax larvae during November 1977. J Fish Biol 21:171-186

Sameoto DD (1988) Feeding on lantern fish Benthosema glaciale off the Nova Scotia Shelf. Mar Ecol Prog Ser 44: 113-129

Sánchez-Velasco L, Contreras-Arredondo I, Esqueda-Escárcega G (1999) Diet composition of Euthynnus lineatus and Auxis sp. larvae (Pisces: Scombridae) in the Gulf of California. Bull Mar Sci 65(3):687-698

Sassa C, Kawaguchi K (2004) Larval feeding habits of Diaphus garmani and Myctophum asperum (Pisces: Myctophidae) in the transition region of the western North Pacific. Mar Ecol Prog Ser 278:279-290

Sassa C, Kawaguchi K, Oozeki Y, Kubota H, Sugisaki H (2004) Distribution patterns of larval myctophid fishes in the transition region of the western North Pacific. Mar Biol 144:417-428

Scharf FS, Juanes F, Rountree RA (2000) Predator size-prey size relationships of marine fish predators: interspecific variation and effects of ontogeny and body size on trophicniche breadth. Mar Ecol Prog Ser 208:229-248

Schoener $\mathrm{T}$ (1968) The Anolis lizards of Bimini: resource partitioning in a complex fauna. Ecology 49:704-726

Schoener T (1974) Resource partitioning in ecological communities. Science 185:27-39

Editorial responsibility: Howard Browman (Associate Editorin-Chief), Bergen, Norway
Shannon CE, Weaver W (1963) The mathematical theory of communication. University of Illinois Press, Urbana

Shirota A (1970) Studies of the mouth size of fish in the larval and fry stages. Bull Jpn Soc Sci Fish 36:353-368

Sobarzo M, Figueroa D (2001) The physical structure of a cold filament in a Chilean upwelling zone (Península de Mejillones, Chile, $23^{\circ} \mathrm{S}$ ). Deep-Sea Res 48:2699-2726

Tyler HR Jr, Pearcy WG (1975) The feeding habits of three species of lanternfishes (Mictophidae) off Oregon, USA. Mar Biol 32:7-11

Watanabe H, Kawaguchi K, Hayashi A (2002) Feeding habits of juvenile surface-migratory myctophid fishes (family Myctophidae) in the Kuroshio region of the western North Pacific. Mar Ecol Prog Ser 236:263-272

Williams A, Koslow JA, Terauds A, Haskard K (2001) Feeding ecology of five fishes from the mid-slope micronekton community off southern Tasmania, Australia. Mar Biol 139:1177-1192

Willis J, Pearcy WG (1982) Vertical distribution and migration of fishes of the lower mesopelagic zone off Oregon. Mar Biol 70:87-98

Wisner RL (1976) The taxonomy and distribution of lanternfishes (family Myctophidae) of the eastern Pacific Ocean. US Government Printing Office, Washington, DC

Young JW, Blaber SJM (1986) Feeding ecology of three species of midwater fishes associated with the continental slope of eastern Tasmania, Australia. Mar Biol 93:147-156

Zar JH (1996) Biostatical analysis, 2nd edn. Prentice-Hall, Upper Saddle River, NJ

Submitted: May 10, 2004; Accepted: December 22, 2004 Proofs received from author(s): March 9, 2005 